\title{
ENVIRONMENTAL IMPACT OF EXPLORATION FROM UNCONVENTIONAL GAS DEPOSITS IN POLAND
}

\author{
WPLYW PRAC POSZUKIWAWCZYCH NA ŚRODOWISKO W EKSPLORACJI \\ NIEKONWENCJONALNYCH ZLÓŻ GAZOWYCH W POLSCE
}

\begin{abstract}
Shale formations have been recently treated only as source rocks and sealing packages mainly of conventional deposits. At present shales, which have a considerable concentration of highly mature organic matter appearing in complexes of over $30 \mathrm{~m}$ thick are used as unconventional sources for natural gas production with the use of advanced drilling technologies. Natural gas production in such rock formations necessitates performing a horizontal section in the borehole and a big number of hydraulic fracturing jobs. The unconventional shale gas deposits have been prospected also in Poland for a couple of years. Exploration works mainly concentrate on a vast area passing from Pomerania through Mazowsze to the Lublin region in Poland. The analysis of the geologic analyses reveals that the most perspective are shales in the Lower Paleozoic at a depth of $2500 \mathrm{~m}$ in the eastern part to about $4000 \mathrm{~m}$ in the western part of the area. The paper is focused on the quantitative and qualitative evaluation of environmental impact of natural gas exploration works from unconventional deposits. Special attention was paid to the hydraulic fracturing jobs in shales, which create particular hazard for water and soil environment. These hazards already appear at the stage of preliminary works, when big quantities of chemicals and water for frac jobs are stored in the rig area, and then, during realization of works, when the spent hydraulic fracturing fluid may penetrate the water-bearing horizons in the caprock. The composition of fracturing fluid used in Gapowo B-1A well are given along with the results of chemical analyses of a few parts of spent fracturing fluid samples pumped out from the borehole. The fluid turned out to be high in salt (high specific electrolyte conductance (SEC) and total dissolved substances (TDS) and a high toxicity for most of the living organisms). For this reason the spent fracturing fluid should not enter the environment without control.
\end{abstract}

Keywords: natural gas, unconventional deposits, shale gas, exploration boreholes, environment, noise, drilling waste, hydraulic fracturing, fracturing fluid, spent fracturing fluid

\section{Introduction}

Classic gas and oil deposits are mainly connected with the process of hydrocarbon migration from source rocks (where hydrocarbons were generated) or reservoir rocks, which have very good hydromechanical properties (high permeability and considerable porosity). These deposits are located in structural, lithofacial or tectonic 'traps' and they

\footnotetext{
${ }^{1}$ Faculty of Drilling, Oil and Gas, AGH University of Science and Technology in Kraków, al. A. Mickiewicza 30, 30-059 Kraków, Poland, phone +48 1261722 26, fax +48 126340052

${ }^{2}$ Polish Geological Institute - National Research Institute, ul. Rakowiecka 4, 00-975 Warszawa, Poland, phone +48 2245920 25, fax +48 2245920 01, email: mkon@pgi.gov.pl

*Corresponding author: macuda@agh.edu.pl
} 
considerably differ in their properties from the unconventional ones. The latter usually have low or ultra low permeability (usually below 0.1 milidarcy [mD] $\left(10^{-16} \mathrm{~m}^{2}\right)$ [1, 2]. Four major kinds of unconventional gas deposits are usually distinguished [3, 4].

- Low permeability gas $(0.1$ to $0.001 \mathrm{mD})$, present in pores of limited contact among them (tight gas).

- Gas (methane) in coal seams, both free and adsorbed (Coal Bed Methane - CBM).

- Gas in clay and mudstones (shale gas, gas in clayey shales).

- Bounded gas in the form of hydrates - no efficient recovery technology.

Shale formations have been recently only treated as source rocks and sealing packages of conventional deposits. At present shales, which have a considerable concentration of organic matter (total organic carbon (TOC) above 1.5-2\%), high thermal maturity index (vitrinite reflectance coefficient (Ro) above 1.3\%) and which occur in complexes of thickness exceeding $30 \mathrm{~m}$ are used as unconventional deposits for advanced production of natural gas [5-7]. Unconventional gas deposits may also cover gas-condensate or purely gaseous deposits $[8,9]$. Determining two-phase zones is vital for gas-condensate deposits $[3,10]$.

A dense grid of directional boreholes with long horizontal sections, where ten or so fracturing jobs are performed, should be performed. These jobs open fractures and a dense network of cracks around them, connecting the biggest possible number of rock pores and forming pathways for the migration of gas to the borehole, both the free and desorbed from organic matter and clayey minerals $[11,12]$.

\section{Characteristic of ,shale" deposits}

Unconventional "shale" deposits are connected with natural gas occurrence in shale formations. In most cases these rocks are thick and they regionally extend with no structural traps or distinct gas/water contour. Additional property, which distinguishes them from classic hydrocarbon deposits is the necessity to use multilateral directional boreholes with long horizontal sections to carry on the production of natural gas [13, 14]. Multigrade hydraulic fracturing jobs are performed in horizontal sections to obtain commercial gas production [15-17].

Organic matter which generates hydrocarbons in shale rocks is kerogen. Its ability to generate hydrocarbons depends on the oxygen to carbon ratio and hydrogen to carbon ratio. The most favorable conditions for hydrocarbons generation was observed for kerogen type-III and partly kerogen type-II as far as gases and gas-condensates are concerned [18, 19].

When evaluating potential resources of natural gas, attention is also paid to TOC and Ro, which is the main component of kerogen [20]. The analysis of literature [3, 12] reveals that shales containing above 1-2\% TOC have sufficient (commercial) amounts of gas, which can be produced. The best shales may reach even $12 \%$ TOC in various places all over the world. Apart from these properties, other reservoir parameters are taken into account: porosity $>4 \%$, permeability $>100$ nanodarcy $\left(>10^{-19} \mathrm{~m}^{2}\right)$, Ro $>1.3-1.5 \%$. Such deposits have a natural system of fractures, though the matrix has a very low permeability 30 to $100 \mathrm{nD}$ [13]. In coal-bed methane deposits the density of natural fractures is a significant parameter $[21,22]$. Natural gas production from such rock formations cannot be performed without additional operations, eg hydraulic fracturing. 


\section{Drilling of exploration boreholes}

Natural gas prospecting and opening unconventional gas deposits is realized through normal-diameter, multilateral drilling boreholes to a depth of a few thousand meters. Such constructions with long horizontal sections are practically the only way in which natural gas can be produced from shales. The exploration boreholes are drilled in the Horizontal Directional Drilling (HDD) technology. The first part is vertical and then at a certain depth it kicks off over the package of productive rocks in such a way that the trajectory is vertical in the moment it reaches the shales level. At present the horizontal sections are mostly 1.5 to $3.5 \mathrm{~km}$ long [13].

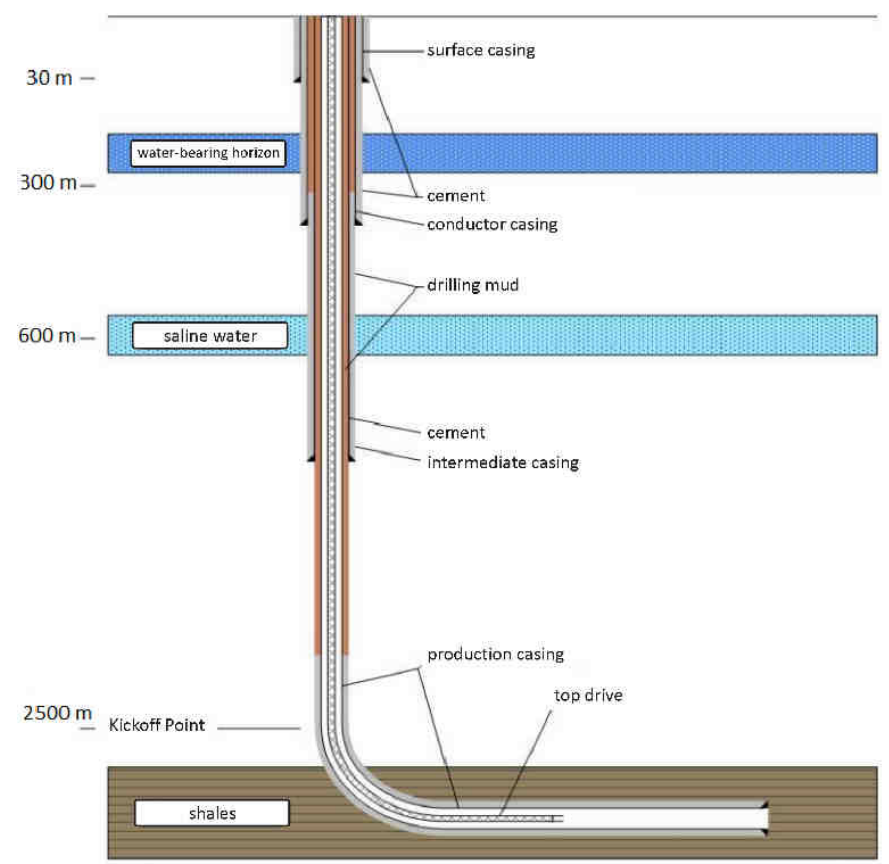

Fig. 1. Schematic of a shale gas exploration borehole [13]

The shale gas boreholes generally resemble exploration boreholes drilled for conventional gas and oil deposits. A typical schematic of an exploration borehole for unconventional deposits is presented in Figure 1. It consists of the following casing sections [14]:

- surface casing - 20 " or $185 / 8$ " - to ca. 50 m of depth

- conductor casing - 13 3/8" - to ca. 500-900 m of depth (depending on the geological conditions in the given region),

- intermediate casing - $95 / 8$ " - to ca. 1500-2500 $\mathrm{m}$ of depth, depending on the geological conditions in the given region,

- production casing - 5" or 5 1/2" 4000-6000 m long with a horizontal section 1000-2500 m long. 
For the sake of providing stability of the drilled rock mass and tightness of the borehole construction all the casing sections are cemented to the surface.

Modern drilling tools are used for the realization of such boreholes. They are frequently set on a mobile base; their lifting capacity on hook is of $350-450 \mathrm{Mg}$ and they are equipped with a Top Drive, 3 mud pumps of hydraulic power ca. (1200 kW) and submersible engine for horizontal drilling. The total capacity of driving motors supplying the rig subassemblies is 3000 to $4000 \mathrm{~kW}$. The transport of the cuttings from the horizontal sections and their geomechanical stability are one of the most important issues while performing exploration boreholes [23].

\section{Environmental impact of drilling on ground and water}

When drilling exploration boreholes on unconventional shale deposits at a depth of 3000 to $4000 \mathrm{~m}$ an area of ca 2.0 to 4.0 ha has to be temporarily occupied and excluded from agricultural or forest production. In either case the size of the occupied area is significantly conditioned by the length of the access road, magnitude of rig subassemblies, depth and number of planned boreholes and capacity of pit where the fracturing fluid will be prepared.

In the course of drilling soil, ground and groundwater may be contaminated with fuel, oils, substances used for making drilling muds, cement slurry, technological fluids and fracturing fluid. Therefore, prior to the construction works within the rig area the state of the ground and water environment has to be analyzed to be able to establish a reference "background", on the basis of which potential changes can be assessed. These are analyses of $\mathrm{CH}_{4}$ concentration in soil air, physicochemical and organic indices of soil, ground, surface water and groundwater. The scope of analyses of soil and ground most frequently covers: specific electrolyte conductance (SEC), AS - anionic surfactants, TDS - total dissolved substances, total organic carbon (TOC), $\mathrm{Fe}, \mathrm{Mn}, \mathrm{B}, \mathrm{Ba}, \mathrm{Na}, \mathrm{Ca}, \mathrm{K}, \mathrm{Br}, \mathrm{Cl}, \mathrm{NO}_{3}$, $\mathrm{NH}_{4}$, phenols (phenol index) as well as petroleum hydrocarbons $\mathrm{C}_{6}-\mathrm{C}_{12}$ and mineral oils $\mathrm{C}_{12}-\mathrm{C}_{35}$ [24].

A considerably broader scope of analyses is planned for groundwater samples. Each time, after measuring the depth of the water level and pumping out 3 borehole volumes the following measurements are made: $\mathrm{pH}$, specific electrolyte conductance (SEC), temperature and oxygen dissolved in water. Then groundwater samples are collected for laboratory analyses, ie [24]:

- general indices: $\mathrm{pH}$, conductivity, turbidity, color, total dissolved solids, general total hardness, chemical oxygen demand $\mathrm{ChOD}, \mathrm{HCO}_{3}$ concentration,

- $\quad$ cations: $\mathrm{Na}, \mathrm{K}, \mathrm{Li}, \mathrm{NH}_{4}, \mathrm{Be}, \mathrm{Ca}, \mathrm{Mg}, \mathrm{B}, \mathrm{Ba}, \mathrm{Sr}, \mathrm{Fe}, \mathrm{Mn}, \mathrm{Ag}, \mathrm{Zn}, \mathrm{Cu}, \mathrm{Ni}, \mathrm{Co}, \mathrm{Pb}, \mathrm{Hg}$, $\mathrm{Cd}$, Se, Al, Cr, As, Mo, V, Sn, Sb, Ti, U,

- $\quad$ anions: $\mathrm{F}, \mathrm{Cl}, \mathrm{Br}, \mathrm{I}, \mathrm{SO}_{4}, \mathrm{CO}_{3}, \mathrm{NO}_{2}, \mathrm{NO}_{3}, \mathrm{HPO}_{4}$,

- undissociated substances: phenol index, chlorophenols, glycols (ethylene glycol and propylene glycol), sum of aliphatic and aromatic hydrocarbons, organic matter, benzene, toluene, ethylbenzene, and xylens (BTEX), polycyclic aromatic hydrocarbons (PAHs), anionic and non-ionic detergents.

The preparation works on the rig lie in sealing the places where potentially dangerous substances are used (machine room, mud room, mud storages, fuel and lubricant storages, waste bins) with geomembrane, above which concrete plates or aggregate are disposed. Chemical substances used in the technological processes as well as the generated waste and 
cuttings are stored in tight tanks or containers. A collector trench is performed around the rig area for the rain waters. These solutions additionally protect the ground and groundwater against migration of contaminations inside the profile when a failure situation takes place. A view of a rig area during realization of the first in Poland exploration shale gas borehole with the use of MASSARENTI rig MAS $5000 \mathrm{E}$ is presented in Figure 2.

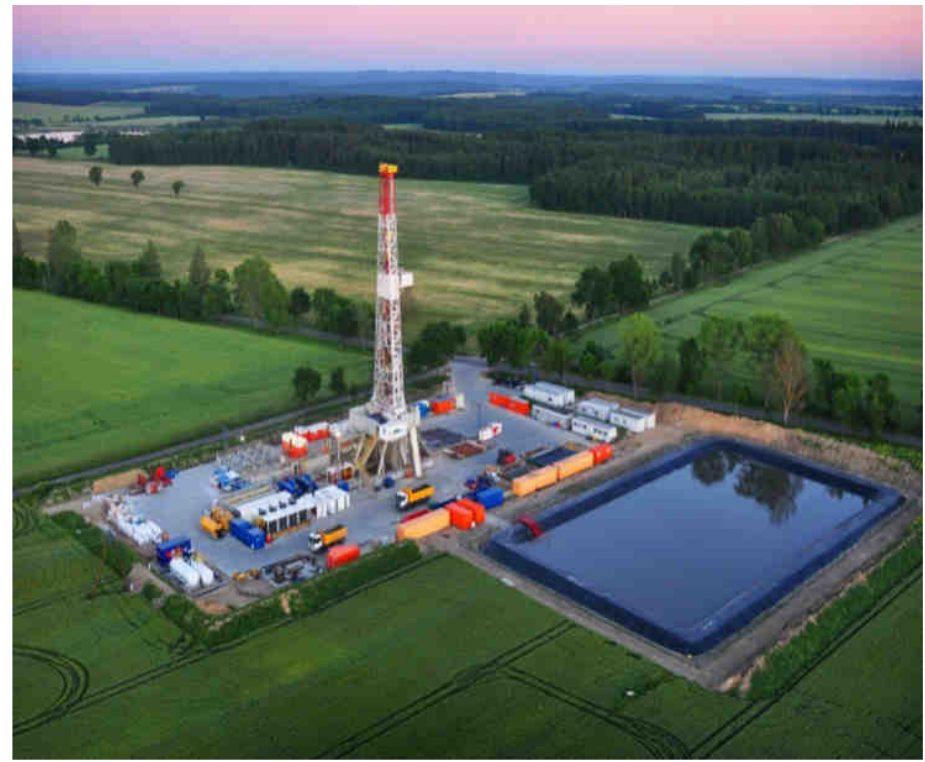

Fig. 2. View of the rig while drilling an exploration borehole with a MASSARENTI rig MAS $5000 \mathrm{E}$ [25]

\section{Noise emission to the environment}

Noise emissions accompanying drilling of deep shale gas exploration boreholes may be also an important environmental issue. When the rig is localized in highly urbanized areas or requires special protection, acoustic screens have to be applied.

Among the major sources of noise in the rig area are: power generators, engines driving rig devices, mud pumps and vibrating sieves. Presently the power aggregates are placed in closed rooms with unprotected walls (poor sound proof), whereas motors and mud pumps are completely or partly protected with a canopy (or partly housed). Vibration sieve shakers are generally unprotected. The distribution of noise level in the surrounding of the MASSARENTI rig MAS $5000 \mathrm{E}$ when drilling a shale gas exploration borehole at $3700 \mathrm{~m}$ is presented in Figure 3. The rig was equipped with a hoist drive in the form of two DC motors 5GE 752 AR of constant power $1100 \mathrm{~kW}$, mud pump drive in the form of 2 electrical engines 5GE $752 \mathrm{AR}$ each and 4 combustion engines Caterpillar $3512 \mathrm{C} 4$ powering electricity generators $(1030 \mathrm{~kW})$. The analysis of the results of acoustic measurements of noise A presented in [25], reveals that depending on the location of subassemblies, particular drilling rigs may affect the environment differently. This can be proved by the distinct directional acoustic plots. Considerable discrepancies in the noise level on the boundary of particular rigs show to the possibility of lowering their 
environmental impact by proper localization of the noisiest subassemblies to protected buildings and by using screening of other subassemblies and machines in the rig area [24]. This refers to a small distance from the rig, ie to about $200 \mathrm{~m}$. Further from that place, the distribution of the noise level around the drilling devices assumes a circular form. In Table 1 we have average ranges of acoustic noxiousness of particular rig elements.

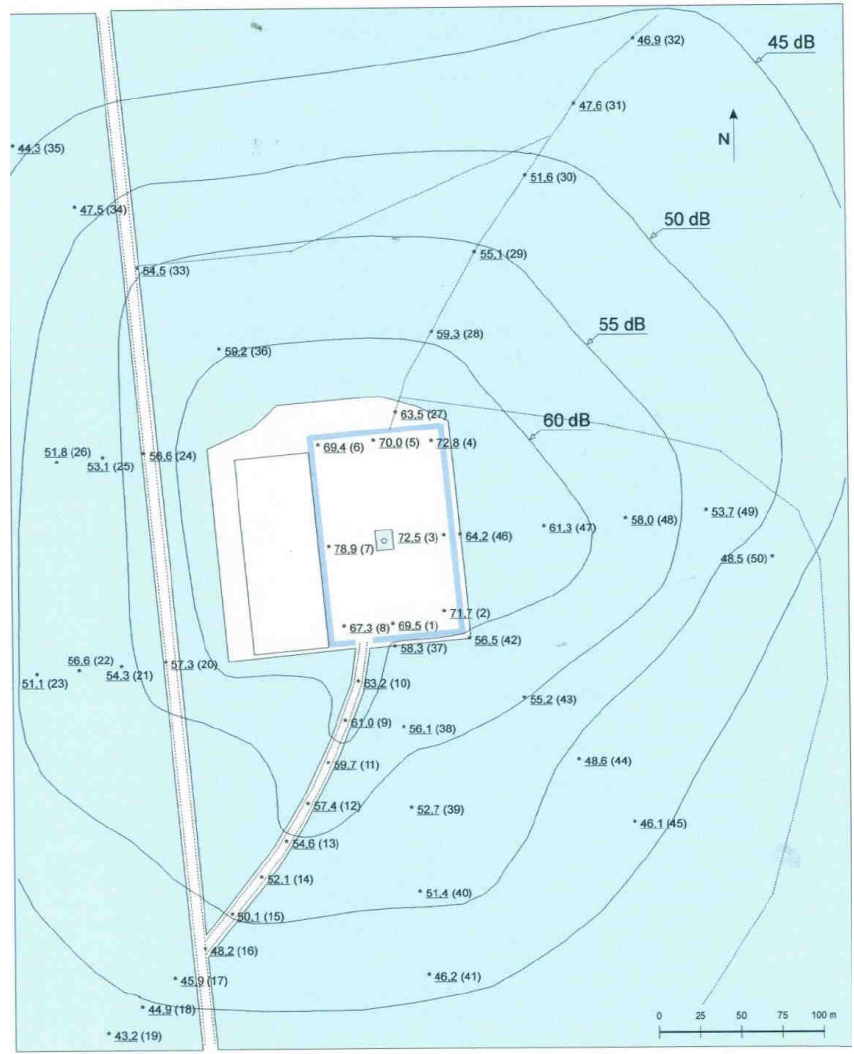

Fig. 3. Distribution of noise level in the neighborhood of the MASSARENTI rig MAS 5000 E [25]

Table 1

Average ranges of isolines 35,40 and $45 \mathrm{~dB}$ for an open area [25]

\begin{tabular}{|c|c|c|c|c|}
\hline \multirow{2}{*}{ No. } & \multirow{2}{*}{ Rig } & \multicolumn{3}{|c|}{ Range of isolines [m] } \\
\cline { 3 - 4 } & & $\mathbf{3 5} \mathbf{~ d B}$ & $\mathbf{4 0 ~ d B}$ & $\mathbf{4 5} \mathbf{~ d B}$ \\
\hline 1 & Drillmec 2000 HP & 635 & 472 & 312 \\
\hline 2 & MASSARENTI MAS 5000 & 672 & 502 & 323 \\
\hline 3 & Bentec EuroRig 450 & 627 & 487 & 309 \\
\hline
\end{tabular}

\section{Types and quantity of precipitations while drilling exploration boreholes}

Drilling precipitations which have diversified chemical composition, mechanical properties and potential environmental toxicity appear in the process of drilling boreholes 
[26]. Taking physicochemical properties as a criterion, the drilling waste can be divided into:

- cuttings coming from all drilled rocks in the borehole profile,

- drilling mud.

Among the main sources of waste present in the precipitations are: chemicals used for making and regulating technological parameters of muds, biocides, oil products, corrosion inhibitors, chemicals used for drilling up and enhancement of hydrocarbon production, reservoir fluids in the form of brine and oil [21].

Depending on the depth of drilling, a few types of mud are used for drilling shale gas exploration boreholes in Poland, eg bentonite, clay-free polymeric mud which reduces hydration of clayey rocks and for drilling up sales (drill in fluid), muds having inhibition qualities and protecting against damage to the permeability of the near-wellbore zone. The type of mud is selected individually on the basis of the geologic, reservoir and technical-technological conditions of drilling. Moreover additional quantities of other waste are produced while drilling a borehole, casing and cementing jobs $e g$ cement slurry residue, waste produced during exploitation of mechanical devices, hydrated sediments from the treatment of industrial waste and communal waste.

Pursuant to the regulation of the Environment Minister of 27 September 2001 about the catalog of waste [27], the waste generated in the process of drilling exploration boreholes can be classified as:

- $010505^{*}$ - mud and drilling waste containing oil,

- $010506^{*}$ - mud and drilling waste containing dangerous substances,

- 010507 - mud containing barite and other waste than listed in 010505 and 010506 ,

- 010508 - mud containing chlorides and waste other than listed in 010505 and 010506 ,

(* - dangerous waste)

Part of the drilling waste are dangerous and while storing in the rig area they should be properly protected against penetrating the ground and water environment [26].

Apart from drilling waste it is also other waste which is generated in the rig area, which belongs to the following groups: 06, 07, 08, 12, 13, 15, 16, 17 and 20. The main types and average quantities of waste produced in the course of drilling exploration boreholes to the depth of $4000 \mathrm{~m}$ are listed in Table 2 .

Quantitative list of major types of waste produced while drilling an exploration borehole to a depth of $4000 \mathrm{~m}$

\begin{tabular}{|c|c|c|c|}
\hline No. & Waste type & $\begin{array}{c}\text { Amount of waste } \\
{[\mathbf{M g}]}\end{array}$ & $\begin{array}{c}\text { Share } \\
{[\%]}\end{array}$ \\
\hline 1 & Waste mud, cuttings & 3904 & 99.874 \\
\hline 2 & Synthetic waste & 0.518 & 0.013 \\
\hline 3 & Used oils & 0.700 & 0.017 \\
\hline 4 & Oiled wipers & 0.190 & 0.004 \\
\hline 5 & $\begin{array}{c}\text { Fluorescence lamps and other waste } \\
\text { containing mercury }\end{array}$ & 0.047 & 0.001 \\
\hline 6 & Welding waste and used electrodes & 0.086 & 0.002 \\
\hline 7 & Iron and steel waste & 3.5 & 0.089 \\
\hline \multicolumn{2}{|c|}{ Total } & 3909.041 & 100.00 \\
\hline
\end{tabular}




\section{Opening shales with the hydraulic fracturing method}

Hydraulic fracturing of shales is performed to liberate gas encapsulated in the rock micropores and adsorbed in the organic matter. After the drilling job is finished and the casing is perforated, large quantities of prepared fracturing water with sand (proppant) are injected into the rock medium to generate and support fractures in the selected interval of the horizontals borehole section (Fig. 4).

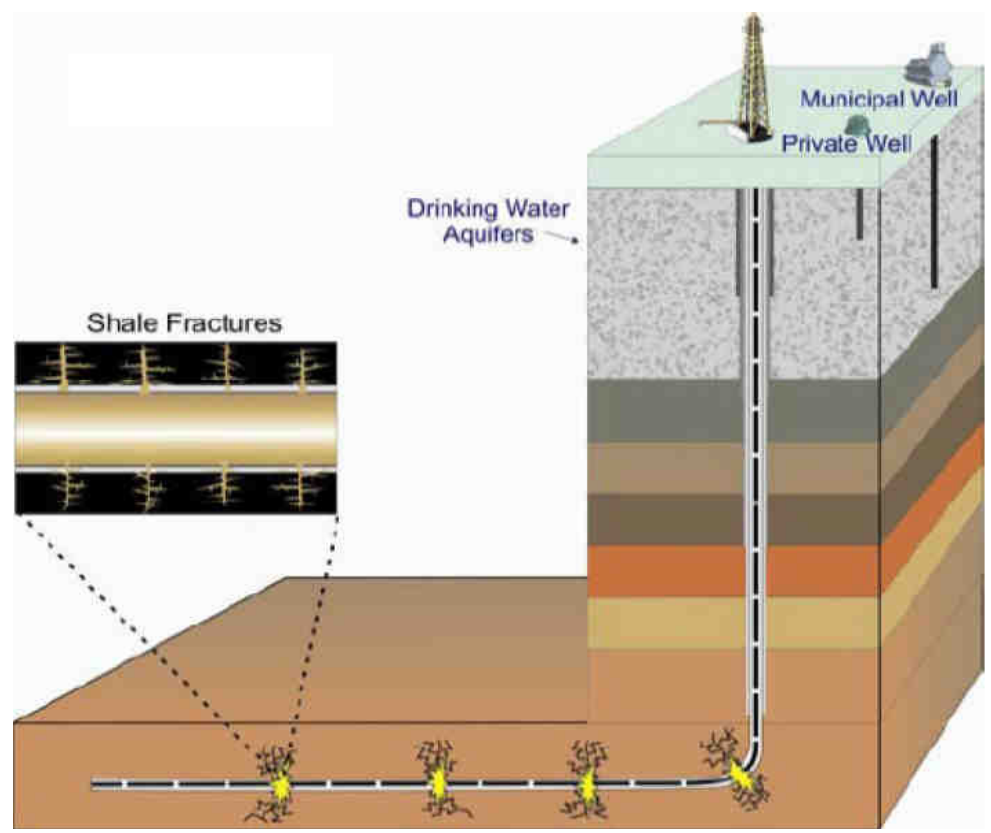

Fig. 4. Schematic of hydraulic fracturing in a horizontal borehole [28]

In industrial practice about 10 to 15 frac jobs are performed in a horizontal section ca. $1500-2000 \mathrm{~m}$ long. On average 8000 to $30000 \mathrm{~m}^{3}$ of fracturing fluid and $500 \mathrm{Mg}$ to 2500 $\mathrm{Mg}$ of proppant are used during one frac job [12]. The water and proppant injection efficiency is 6 to $20 \mathrm{~m}^{3} / \mathrm{min}$, at the pumping pressure of $100 \mathrm{MPa}[17,29]$. The hydraulic fracturing job helps propagate the fracture at a distance of 200 to $300 \mathrm{~m}$ [22].

\section{Facturing fluids}

The fracturing fluid used in shale rock is mainly made of water, sand and a small amount of various chemicals. Their task is to lower friction when the fluid is pumped, lower surface tension, form gel, prevent scale formation and corrosion of production pipes, adjust $\mathrm{pH}$, prevent development of bacteria and stabilization of clayey particles concentration in the fluid. Fracturing fluid consists of water in $90.5 \%$, sand in $9 \%$ and chemicals in $0.5 \%$ (Fig. 5). 


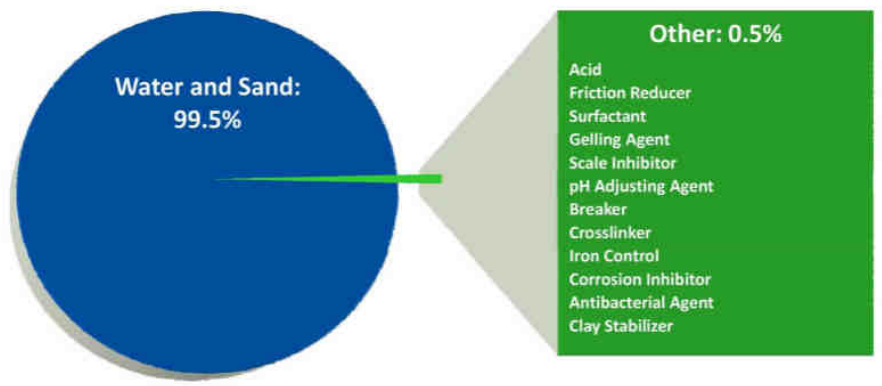

Fig. 5. Concentration of technological substances in fracturing fluid [14]

Composition of fracturing fluid in Gapowo B-1A [30]

\begin{tabular}{|c|c|c|}
\hline $\begin{array}{l}\text { Hydraulic fracturing fluid } \\
\text { composition: Chemical substance } \\
\text { in fracturing fluid }\end{array}$ & $\begin{array}{c}\text { Chemical Abstract Service } \\
\text { number (CAS) }\end{array}$ & $\begin{array}{c}\text { Maximum ingredient concentration } \\
\text { in hydraulic fracturing fluid } \\
{[\% \text { by mass }]}\end{array}$ \\
\hline Water & $7732-18-5$ & 97.26231769 \\
\hline Silica substrate & $66402-68-4$ & 0.96243748 \\
\hline Mullite & $1302-93-8$ & 0.91411425 \\
\hline Silicon dioxide & $7631-86-9$ & 0.26117550 \\
\hline Silica crystalline-cristobalite & $14464-46-1$ & 0.13058775 \\
\hline Choline chloride & $67-48-1$ & 0.12834003 \\
\hline Hydrochloric acid & 7647-01-0 & 0.10916275 \\
\hline Sasol DHR 200 & $64742-48-9$ & 0.07389841 \\
\hline Guar gum powder & Proprietary & 0.06608919 \\
\hline $\begin{array}{c}\text { Colemanite/ulexite } \\
\text { distillates, (petroleum), } \\
\text { hydrotreated light }\end{array}$ & $\begin{array}{l}\text { Proprietary Blend } \\
64742-47-8\end{array}$ & $\begin{array}{l}0.03476695 \\
0.01957735\end{array}$ \\
\hline Potassium carbonate & $584-08-7$ & 0.00847536 \\
\hline Gluteraldehyde & $111-30-8$ & 0.00816513 \\
\hline Potassium hydroxide & $1310-58-3$ & 0.00516431 \\
\hline Elementis Bentone $® 150$ & $\begin{array}{c}\text { 14808-60-7 (Quartz), } \\
\text { 629-11-8 (1,6-Hexanediol) }\end{array}$ & 0.00361538 \\
\hline Tetrasodium EDTA & $64-02-8$ & 0.00210192 \\
\hline Alcohols, $\mathrm{C}_{12-15}$, ethoxylated & $68131-39-5$ & 0.00189248 \\
\hline Propylene glycol & $57-55-6$ & 0.00187365 \\
\hline Ammonium persulfate & $7727-54-0$ & 0.00178336 \\
\hline Formic acid & $64-18-6$ & 0.00093683 \\
\hline Cinnamaldehyde & $104-55-2$ & 0.00093683 \\
\hline Propylene carbonate & $108-32-7$ & 0.00072308 \\
\hline Ethylene glycol & $107-21-1$ & 0.00047460 \\
\hline Oxyalkylated alcohol based polymer & $34398-01-1$ & 0.00031228 \\
\hline N-naphtha nicotinamide & $770680-45-0$ & 0.00031228 \\
\hline Lutensol TO-8 $(1,6)$ hexanediol & $629-11-8$ & 0.00028923 \\
\hline Methanol & $67-56-1$ & 0.00016330 \\
\hline Crystalline silica (quartz) & $14808-60-7$ & 0.00013749 \\
\hline Trisodium nitrilotriacetate & $5064-31-3$ & 0.00010510 \\
\hline Sodium hydroxide & $1310-73-2$ & 0.00007006 \\
\hline
\end{tabular}


The composition of fracturing fluid depends on the properties of rocks to be fractured in a given place, technology and design of the borehole, and also the fracturing technology $[15,29]$. In practice the fracturing fluid used for drilling exploration boreholes does not have any stable composition. These are mixtures sequentially added and their composition is adjusted during the job, depending on the indications of control devices. This stems from the fact that other components are needed for making fractures in shales, other are used to stop swelling of clayey minerals and still different to maintain the proppant in fluid, so that it can be injected to the fracture to support it and then 'break' the structure of the suspension to pump out the used frac fluid and hydrocarbons without removing proppant from the fracture. As a consequence it is practically impossible to take a representative frac fluid sample, and its characteristic is determined by giving an interval of concentrations or maximum concentrations of particular substances (Table 3).

According to the Polish and EU law all chemical substances used in the process of hydraulic fracturing should be admitted to use in Europe and have characteristics, which precisely determine their chemical and physical properties, toxicity, hazard and neutralization methods in case of uncontrollable contact with people or environment. The charts are used for elaborating emergency procedures in case of undesired events during transport and storage of particular substances and the hydraulic fracturing job. If the job is performed carefully, the fracturing fluid practically does not have contact with the environment before the depth of fracturing, which in Poland is at least $2500 \mathrm{~m}$ b.s.

The water demand is environmentally important for hydraulic fracturing. One frac job requires as much as a tens of cubic meters of water which is used in a few days' time. Very rarely such amounts are available from local sources on demand. Besides a momentary consumption of such a big amount of water could negatively influence the groundwater and surface water resources. Therefore accumulation of water for hydraulic fracturing jobs should be realized over a sufficiently long period of time so that the available resources are not exceeded. The sources frequently have to be diversified and in particular cases water has to be transported from more distant places. This is environmentally advantageous when not only fresh waters are used, but also brines, rain waters, treated sewage and treated used fracturing fluid. The use of such alternative sources of water is regulated by the respective legal acts. At present only some of these sources could be used in Poland.

\section{Used fracturing fluids}

After the frac job is completed, some quantity of fracturing fluid returns through the open head to the surface. This fluid differs from the injected fracturing fluid because it gains new properties after contacting the rock, reservoir fluids and chemical reactions between the original components in the high pressure and temperature conditions. Analogous to the fracturing fluid, the chemical composition of reservoir fluid is not constant, though by controlling the pressure on the outflow and collecting samples sufficiently frequently, one can make a characteristic of the successive parts.

Varying yields of spent fracturing fluid return to the surface but generally about $15-20 \%$ of the injected fluid returns to the surface after a few days. The boreholes are deep in Poland therefore spontaneous outflows vanish very quickly. For this reason either gaslift or specialist pumps have to be used to produce larger amounts of fluid.

Hydrocarbons are one of the most characteristic components of the spent fracturing fluid. Even in the lack of industrial inflows of reservoir fluids, certain amounts of natural 
gas and condensate can be expected (Table 4). These substances have to be separated from the return fluid before it is sent to the collectors, where it is finally stored. These are two- or three-phase separators which remove gas from it and allow for collecting liquid hydrocarbons to special tight containers. The collected condensate has an industrial application, whereas methane from the exploration boreholes is most frequently combusted on flares. The combustion (Fig. 6) causes that almost $100 \%$ of carbon dioxide and vapor reach the atmosphere instead of methane, which is more efficient as far as the greenhouse effect is concerned.

Exemplary determining organic indices in the successive parts of past-fracture fluid [31]

\begin{tabular}{|c|c|c|c|c|}
\hline \multirow{2}{*}{ Sample No. } & Benzene & BTEX & Methane & $\begin{array}{c}\text { Hydrocarbons } \\
\mathbf{C}_{\mathbf{2}}-\mathbf{C}_{\mathbf{1 0}}\end{array}$ \\
\cline { 2 - 5 } & \multicolumn{4}{|c|}{$\left[\boldsymbol{\mu \mathbf { g } / \mathbf { d m } ^ { 3 } ]}\right.$} \\
\hline 1 & $<0.5$ & $<0.5$ & 1368 & 1253 \\
\hline 2 & $<0.5$ & $<0.5$ & 3505 & 3113 \\
\hline 3 & $<0.5$ & $<0.5$ & 1889 & 358 \\
\hline $\begin{array}{c}4 \text { (behind } \\
\text { separator) }\end{array}$ & $<0.5$ & $<0.5$ & 144 & 306 \\
\hline $\begin{array}{c}5 \text { (behind } \\
\text { separator) }\end{array}$ & $<0.5$ & $<0.5$ & 120 & \\
\hline
\end{tabular}

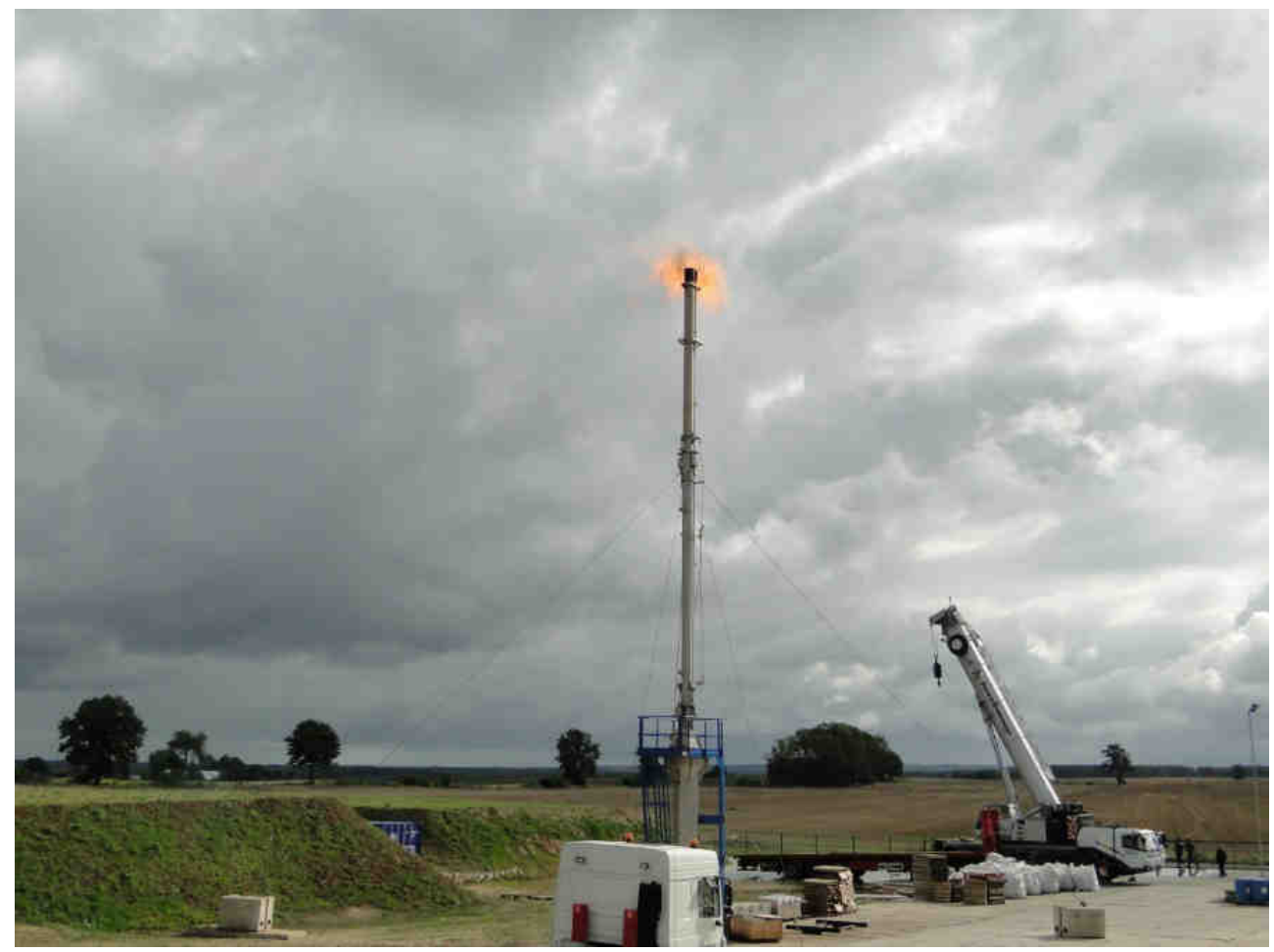

Fig. 6. Combustion of natural gas separated from spent fracturing fluid after the frac job 
Table 5

Exemplary physicochemical characteristic of successive parts of fluids returning from the same frac job [31]

\begin{tabular}{|c|c|c|c|c|c|c|c|c|c|c|c|}
\hline \multirow{2}{*}{$\begin{array}{c}\text { Sample } \\
\text { No. }\end{array}$} & & \multirow{2}{*}{$\begin{array}{c}\mathrm{SEC} \\
{[\mu \mathrm{S} / \mathrm{cm}]}\end{array}$} & \multirow{2}{*}{\begin{tabular}{|c|} 
Colour \\
$\begin{array}{c}{[\mathrm{mg} \mathrm{Pt} /} \\
\left.\mathbf{d m}^{3}\right]\end{array}$ \\
\end{tabular}} & \multirow{2}{*}{$\begin{array}{c}\text { Turbidity } \\
\text { [NTU] }\end{array}$} & ChOD & PhI & Cyanides & AS & TDS & $\begin{array}{l}\text { General } \\
\text { basicity }\end{array}$ & $\begin{array}{l}\text { General } \\
\text { hardness }\end{array}$ \\
\hline & - & & & & \multicolumn{5}{|c|}{$\left[\mathrm{mg} / \mathrm{dm}^{3}\right]$} & \multicolumn{2}{|c|}{$\left[\mathrm{mg} \mathrm{CaCO}_{3} / \mathrm{dm}^{3}\right]$} \\
\hline 1 & 6.67 & 90000 & 130 & 0.7 & 60 & $<10$ & $<1$ & 15 & 91006 & 168 & 12329 \\
\hline 2 & 6.60 & 100000 & 20 & 0.4 & 46 & $<10$ & $<1$ & 29 & 68448 & 152 & 14103 \\
\hline 3 & 6.55 & 101000 & 128 & 0.5 & 70 & $<10$ & $<1$ & 16 & 68472 & 156 & 14366 \\
\hline 4 & 7.01 & 107000 & 90 & 2.7 & 92 & $<10$ & $<1$ & 13 & 73769 & 240 & 15971 \\
\hline 5 & 7.03 & 109000 & 159 & 0.7 & 69 & $<10$ & $<1$ & 19 & 72148 & 210 & 16301 \\
\hline
\end{tabular}

SEC - specific electrolyte conductance, ChOD - chemical oxygen demand, PhI - phenol index, AS - anionic surfactants, TDS - total dissolved solids

Table 6 Exemplary concentrations of anionic components in the successive parts of fluid returning from the same job [31]

\begin{tabular}{|c|c|c|c|c|c|c|c|}
\hline \multirow{2}{*}{ Sample No. } & $\mathbf{F}$ & $\mathbf{C l}$ & $\mathbf{N O}_{\mathbf{2}}$ & $\mathbf{B r}$ & $\mathbf{N O}_{\mathbf{3}}$ & $\mathbf{H P O}_{\mathbf{4}}$ & $\mathbf{S O}_{\mathbf{4}}$ \\
\cline { 2 - 8 } & \multicolumn{7}{|c|}{$\left[\mathbf{m g / \mathbf { d m } ^ { 3 } ]}\right.$} \\
\hline 1 & 5.40 & 37000 & 5.88 & 473 & 4.72 & $<30$ & $<50$ \\
\hline 2 & $<10$ & 42000 & 6.23 & 526 & 4.91 & $<30$ & $<50$ \\
\hline 3 & $<10$ & 42000 & 6.05 & 531 & 6.38 & $<30$ & $<50$ \\
\hline 4 & $<10$ & 45000 & 7.20 & 605 & 5.0 & $<30$ & $<50$ \\
\hline 5 & $<10$ & 43000 & 6.86 & 565 & 5.63 & $<30$ & $<50$ \\
\hline
\end{tabular}

Exemplary concentrations of cationic components in the successive parts of fluid returning from the same job [31]

\begin{tabular}{|c|c|c|c|c|c|c|c|c|c|c|c|}
\hline $\begin{array}{c}\text { Sample } \\
\text { No. }\end{array}$ & B & $\mathbf{B a}$ & $\mathbf{C a}$ & $\mathrm{Cr}$ & $\mathbf{F e}$ & $\mathbf{K}$ & Mg & Mn & $\mathbf{N a}$ & $\mathbf{P}$ & $\mathrm{SiO}_{2}$ \\
\hline & \multicolumn{11}{|c|}{$\left[\mathrm{mg} / \mathrm{dm}^{3}\right]$} \\
\hline 1 & 38.0 & 53.6 & 4120.0 & $<0.3$ & 9.0 & 428.0 & 495.0 & 2.4 & 17598.0 & $<5.0$ & 64.0 \\
\hline 2 & 39.0 & 60.9 & 4720.0 & $<0$. & 11.0 & 467.0 & 563.0 & 2.4 & 19215.0 & $<5.0$ & 61.0 \\
\hline 3 & 39.0 & 61.2 & 4804.0 & $<0.3$ & 11.0 & 462.0 & 576.0 & 2.4 & 19131.0 & $<5.0$ & 61.0 \\
\hline 4 & 39.0 & 69.0 & 5351.0 & $<0.3$ & 11.0 & 489.0 & 634.0 & 2.5 & 20528.0 & $<5.0$ & 57.0 \\
\hline 5 & 39.0 & 70.4 & 5461.0 & $<0.3$ & 12.0 & 499.0 & 647.0 & 2.6 & 20843.0 & $<5.0$ & 59.0 \\
\hline \multirow{2}{*}{$\begin{array}{c}\text { Sample } \\
\text { No. }\end{array}$} & $\mathrm{Sr}$ & $\mathbf{T i}$ & $\mathbf{Z n}$ & $\mathrm{Hg}$ & $\mathbf{L i}$ & Be & Al & $\mathbf{V}$ & Co & $\mathbf{N i}$ & $\mathrm{Cu}$ \\
\hline & \multicolumn{3}{|c|}{$\left[\mathrm{mg} / \mathrm{dm}^{3}\right]$} & \multicolumn{8}{|c|}{$\left[\mu \mathrm{g} / \mathrm{dm}^{3}\right]$} \\
\hline 1 & 380.0 & 0.3 & $<0.3$ & $<0.3$ & 8800 & $<50$ & $<500$ & $<1000$ & $<50$ & $<500$ & $<500$ \\
\hline 2 & 452.0 & 0.3 & $<0.3$ & $<0.3$ & 10000 & $<50$ & $<500$ & $<1000$ & $<50$ & $<500$ & $<500$ \\
\hline 3 & 456.0 & 0.4 & $<0.3$ & $<0.3$ & 10300 & $<50$ & $<500$ & $<1000$ & $<50$ & $<500$ & $<500$ \\
\hline 4 & 505.0 & 0.4 & $<0.3$ & $<0.3$ & 11600 & $<50$ & $<500$ & $<1000$ & $<50$ & $<500$ & $<500$ \\
\hline 5 & 523.0 & 0.4 & $<0.3$ & $<0.3$ & 12000 & $<50$ & $<500$ & $<1000$ & $<50$ & $<500$ & $<500$ \\
\hline \multirow{2}{*}{$\begin{array}{c}\text { Sample } \\
\text { No. }\end{array}$} & As & Se & Mo & Ag & Cd & Sn & Sb & TI & $\mathbf{P b}$ & $\mathbf{U}$ & \\
\hline & \multicolumn{10}{|c|}{$\left[\mu \mathrm{g} / \mathrm{dm}^{3}\right]$} & \\
\hline 1 & $<2000$ & $<2000$ & $<50$ & $<50$ & $<50$ & $<500$ & $<50$ & $<50$ & $<100$ & $<50$ & - \\
\hline 2 & $<2000$ & $<2000$ & $<50$ & $<50$ & $<50$ & $<500$ & $<50$ & $<50$ & $<100$ & $<50$ & - \\
\hline 3 & $<2000$ & $<2000$ & $<50$ & $<50$ & $<50$ & $<500$ & $<50$ & $<50$ & $<100$ & $<50$ & - \\
\hline 4 & $<2000$ & $<2000$ & $<50$ & $<50$ & $<50$ & $<500$ & $<50$ & $<50$ & $<100$ & $<50$ & - \\
\hline 5 & $<2000$ & $<2000$ & $<50$ & $<50$ & $<50$ & $<500$ & $<50$ & $<50$ & $<100$ & $<50$ & - \\
\hline
\end{tabular}


Apart from water, the remaining components of the used fracturing fluid are substances used for the preparation of the fracturing fluid, frequently after chemical reactions, and dissolved solids and liquids of rock formations undergoing the frac job. The basic physicochemical characteristic of the successive parts of the used fracturing fluid from the exploration borehole in the Lublin area is presented in Table 5. Very high salt content manifesting itself in high SEC and TDS causes that the fluid is toxic to most of the living organisms, therefore cannot be disposed to the natural environment without control.

What is characteristic here is a very high, up to tens of grams per liter concentration of chlorides (Table 6), sodium, calcium and potassium (Table 7). Exemplary changes in the concentrations of successive parts of the returning fluids during one frac job are listed in Tables 6 and 7 .

In some regions increased concentrations of radioactive elements can be also expected in fracturing fluids which return to the surface after the job. This mainly refers to frac jobs in such formations which were enriched in natural radio nuclides. No higher than naturally occurring and safe for human being radioactive isotopes have been found in the used fracturing fluids in Poland [31], ie:

- for ${ }^{40} \mathrm{~K}: 51 \pm 11$ to $347 \pm 20 \mathrm{~Bq} / \mathrm{kg}$ (in Pomeranian Basin) and $12 \pm 7$ to $492 \pm 35 \mathrm{~Bq} / \mathrm{kg}$ (in Lublin Basin);

- for ${ }^{226} \mathrm{Ra}:<10$ to $48 \pm 4 \mathrm{~Bq} / \mathrm{kg}$ (in Pomeranian Basin) and $19 \pm 3$ to $29 \pm 3 \mathrm{~Bq} / \mathrm{kg}$ (in Lublin Basin);

- for ${ }^{228} \mathrm{Th}$ : $<10$ to $21 \pm 3 \mathrm{~Bq} / \mathrm{kg}$ (in Pomeranian Basin) and $<10 \mathrm{~Bq} / \mathrm{kg}$ (in Lublin Basin).

\section{Conclusions}

The presented evaluation of environmental impact of exploration works for hydrocarbons from unconventional deposits reveals that both the drilling works and hydraulic jobs create a slightly bigger hazard than in the case of conventional deposits. In Poland shales appear at great depth therefore the exploration boreholes have to be deep. Moreover, the rigs have to have better technical parameters and installed capacity of driving motors. When drilling such boreholes more space is needed for the rig, more waste is generated and more noise is emitted to the environment than in the conventional deposits. This is particularly important when performing numerous and extensive hydraulic fracturing jobs on the shales. In such conditions the reuse of the fracturing fluid for the successive hydraulic fracturing jobs is a good solution. This however requires very efficient technologies of treating the fluid mainly from hydrocarbons, dissolved salts and chemicals used when preparing the fluid. In addition, special guidelines for the environmental and technological aspects of conducting drilling and hydraulic fracturing jobs in shales should be worked out to guarantee safe exploration and extraction of hydrocarbons from unconventional deposits.

\section{Acknowledgements}

This work was done as a result the support of the AGH University of Science and Technology Research Programs no. 11.11.190.555. 


\section{References}

[1] Unconventional Gas, Topic Paper \#29: Working Doc. of the NPC Global Oil \& Gas Study, National Petroleum Council Unc. Gas Subgroup of the Technology Task Group of the NPC Committee on Global Oil and Gas; 2007; 18 July. http://www.npc.org/Study_Topic_Papers/29-TTG-Unconventional-Gas.

[2] Karacan CÖ, Ruiz FA, Cotè M, Phipps S. Coal mine methane: A review of capture and utilization practices with benefits to mining safety and to greenhouse gas reduction, Int J Coal Geol. 2011;86:121-156. http://dx.doi.org/10.1016/j.coal.2011.02.009.

[3] Nagy S, Siemek J. Confinement Phase Envelope of Gas Condensate Systems in Shale Rocks. Arch Min Sci. 2014;59(4):1005-1022. DOI: 10.2478/amsc-2014-0069.

[4] EIA. Technically Recoverable Shale Oil and Shale Gas Resources: An Assessment of 137 Shale Formations in 41 Countries Outside the United States, Washington D.C.2013. http://www.eia.gov/analysis/ studies/worldshalegas/pdf/overview.pdf.

[5] Boyer C, Kieschnick J, Suarez-Rivera R, Lewis ER, Waters G. Producing Gas from Its Source. Oilfield Review. 2006;18(3):36-49.

[6] Siemek J, Nagy S, Siemek P. Challenges for sustainable development: the case of shale gas exploitation in Poland. Problems Sust Develop. 2013;8(1):91-104. http://ekorozwoj.pol.lublin.pl/no15/j.pdf.

[7] Nagy S, Badouard T, Desbrosses N, Deane P, Glynn L. Shale gas prospects for Europe, Hot Energy Topic, Insight E. Brussels: 2014.

[8] Zhang Y, Civan F, Devegowda D, Jamili A, Sigal R. Critical Evaluation of Equations of State for Multicomponent Hydrocarbon Fluids in Organic Rich Shale Reservoirs. Unconventional Resources Technology Conference, Denver: 2013; Paper SPE 1581765.

[9] Behmanesh H, Hamdi H, Clarkson CR. Production Data Analysis of Liquid Rich Shale Gas Condensate Reservoirs. SPE Unconventional Resources Conference-Canada held in Calgary, Alberta, Canada, 2013; November 5-7. Paper SPE 167160-MS. DOI: 10.2118/167160-MS.

[10] Firincioglu T. Bubble point suppression in unconventional liquids rich reservoirs and its impact on oil production. [PhD Thesis]. Golden: Colorado School of Mines; 2013.

[11] Javadpour F, Fisher D, Unsworth M. Nanoscale Gas Flow in Shale Gas Sediments. J Can Petrol Technol. 2007;46(10):55-61. DOI: 10.2118/07-10-06

[12] Javadpour F. Nanopores and Apparent Permeability of Gas Flow in Mudrocks (Shales and Siltstone). J Canad Petrol Technol. 2009;48(8):16-21. DOI: 10.2118/09-08-16-DA.

[13] Modern Shale Gas Development in the United States: A Primer. U.S. Department of Energy. Oklahoma City; 2009. http://energy.gov/sites/prod/files/2013/03/f0/ShaleGasPrimer_Online_4-2009.

[14] McClendon AK. Shale Gas and America's Future. AAPG (American Association of Petroleum Geologists) Convention, 2010; 11-14 April. New Orleans, LA. http://www.searchanddiscovery.com/pdfz/ documents/2010/110141mcclendon/ndx_mcclendon.pdf.

[15] Economides MJ, Watters LT, Dunn-Norman S. Petroleum Well Construction. Chichester: John Wiley \& Sons; 1998.

[16] Lazemi HA, Marji MF, Bafghi AR, Goshtasbi K. Rock failure analysis of the broken zone around a circular opening. Arch Min Sci. 2013;58(1):165-188. DOI: 10.2478/amsc-2013-0012.

[17] Davies RJ, Mathias SA, Moss J, Hustoft S, Newport L. Hydraulic fractures: How far can they go? Mar Petrol Geol. 2012;37(1):1-6. DOI: 10.1016/j.marpetgeo.2012.04.001.

[18] Passey QR, Creaney S, Kulla JB, Moretti, FJ, Stroud, JD. A practical model for organic richness from porosity and resistivity logs. AAPG Bull. 1990;12:1777-1794.

[19] Welte DH, Horfield B, Barker DR. Petroleum and Basin Evolution. New York: Springer; 1997: 535.

[20] Kotarba MJ. Origin of hydrocarbon gases accumulated in the Middle Cambrian reservoirs of the Polish part of the Baltic region. Geolog Quart. 2010;54(2):197-204.

[21] Wadas M. Method for determination of the range of failure zone around macrocracks surface in rock medium. Arch Min Sci. 2013;58(1):269-282. DOI: 10.2478/amsc-2013-0019.

[22] Shabani KS, Ardejani FD, Badii K, Olya ME. Acid mine drainage treatment by perlite nanomineral, batch and continuous systems, Arch Min Sci. 2014;59(1):107-122. DOI: 10.2478/amsc-2014-0008.

[23] King G. Hydraulic Fracturing 101: What Every Representative, Environmentalist, Regulator, Reporter, Investor, University Researcher, Neighbor and Engineer Should Know About Estimating Frac Risk and Improving Fracturing Performance in Unconventional Oas \& Oilwells, SPE 152596, presented at SPE Hydraulic Fracturing Technology Conference held in The Woodlands, Texas, USA. 2012; 6-8 February.

[24] Zawisza L. Ocena zagrożeń dla środowiska naturalnego występujących przy poszukiwaniu i rozpoznawaniu oraz podczas eksploatacji złóż węglowodorów. (Evaluation of environmental hazards during prospecting, recognition and production of hydrocarbons) Praca sfinansowana ze środków NFOŚiGW. Wydział 
Wiertnictwa, Nafty i Gazu AGH. (Financed from the National Fund for Environmental Protection and Water Management. Faculty of Drilling Oil and Gas AGH-UST 2007; Kraków.

[25] Materiały archiwalne. (Archival materials) Poszukiwania Nafty i Gazu NAFTA Sp. z o.o. w Pile (Oil and Gas Prospecting Company Ltd. in Piła), 2010.

[26] Molladavoodi H. Study of ground response curve (grc) based on a damage model. Arch Min Sci. 2013;58(3):655-672. DOI: 10.2478/amsc-2013-0046.

[27] Rozporządzenie Ministra Środowiska z dnia 9 grudnia 2014 r. w sprawie katalogu odpadów (Dz.U. 2014 poz. 1923). (Regulation of the Environment Minister of 9 December 2014 about the catalogue of waste; Official Journal of 2014, item 1923). www.sejm.gov.pl.

[28] Wood R, Gilbert P, Sharmina M, Anderson K, Footitt A, Glynn N, et al. Shale gas: a provisional assessment of climate change and environmental impacts. A research report by The Tyndall Centre University of Manchester. 2011. eScholarID:179208.

[29] Kuljabekov AB, Inkarbekov MK, Tungatarova MS, Alibayeva KA, Kaltayev A. Numerical study of the hydrodynamic efficiency of the multi-stage filter setting technology. Arch Min Sci. 2013;58(3):691-704. DOI: 10.2478/amsc-2013-0048.

[30] www.opppw.pl/projekt/BNK Petroleum Gapowo B-1A Full Chemical Disclosure Final.pdf. (5.08.2015).

[31] Projekt badawczy „Ocena zagrożeń dla środowiska powodowanych procesem poszukiwania, rozpoznawania i wydobywania niekonwencjonalnych złóż węglowodorów". (Reserach project "Evaluation of environmental hazard caused by prospecting, recognition and production of unconventional deposits of hydrocarbons"). Polish Geological Insitute-National Research Institute, Warszawa: AGH University of Science and Technology in Krakow, Gdańsk University of Technology; 2015.

\title{
WPLYW PRAC POSZUKIWAWCZYCH NA ŚRODOWISKO W EKSPLORACJI GAZOWYCH ZŁÓŻ NIEKONWENCJONALNYCH W POLSCE
}

\author{
${ }^{1}$ Wydział Wiertnictwa, Nafty i Gazu, Akademia Górniczo-Hutnicza im. Stanisława Staszica w Krakowie \\ ${ }^{2}$ Państwowy Instytut Geologiczny Państwowy Instytut Badawczy, Warszawa
}

\begin{abstract}
Abstrakt: Formacje łupków do niedawna traktowane były jedynie jako skały macierzyste i pakiety uszczelniające głównie dla złóż konwencjonalnych. Aktualnie w świecie skały łupkowe, które charakteryzują się znaczną koncentracją materii organicznej o wysokiej dojrzałości termicznej i występujące w kompleksach o miąższości powyżej $30 \mathrm{~m}$, są wykorzystywane jako złoża niekonwencjonalne do eksploatacji z nich gazu ziemnego przy wykorzystaniu zaawansowanych technologii wiertniczych. Wydobycie gazu ziemnego z takich formacji skalnych wiąże się z wykonaniem w poziomym odcinku otworu dużej ilości zabiegów hydraulicznego szczelinowania skał. W Polsce od kilku lat prowadzone są również prace poszukiwawcze niekonwencjonalnych złóż gazu ziemnego w skałach łupkowych. Koncentrują się one głównie w szerokim pasie ich występowania, przebiegającym przez Polskę od Pomorza poprzez Mazowsze po Lubelszczyznę. Z analizy dotychczasowych badań geologicznych wynika, że najbardziej perspektywiczne jest występowanie tego typu złóż w skałach łupkowych dolnego paleozoiku, zalegających na głębokościach od $2500 \mathrm{~m}$ we wschodniej części tego pasa do około $4000 \mathrm{~m}$ w jego części zachodniej. W pracy skoncentrowano się głównie na ilościowej i jakościowej ocenie wpływu prac poszukiwawczych za gazem ziemnym w złożach niekonwencjonalnych na środowisko naturalne. Szczególną uwagę zwrócono na zabiegi hydraulicznego szczelinowania skał łupkowych, które stwarzają największe zagrożenia dla środowiska gruntowo-wodnego. Zagrożenia te występują już na etapie prac przygotowawczych, w wyniku magazynowania na wiertni dużych ilości środków chemicznych i wody do zabiegów szczelinowania oraz w trakcie ich realizacji w wyniku potencjalnej możliwości przedostania się płynu pozabiegowego do występujących w nadkładzie utworów wodonośnych. W pracy podano skład cieczy szczelinującej użytej do zabiegu w otworze Gapowo B-1A oraz wyniki analiz chemicznych kilku partii płynu pozabiegowego, odpompowanego z otworu. Stwierdzono jego wysokie zasolenie, przejawiające się wysokimi wartościami parametrów PEW i SSR oraz dużą toksyczność w stosunku do większości organizmów żywych. Z tego względu płyn pozabiegowy nie może dostawać się do środowiska w sposób niekontrolowany.
\end{abstract}

Słowa kluczowe: gaz ziemny, złoża niekonwencjonalne, gaz z łupków, otwory poszukiwawcze, środowisko, hałas, odpady wiertnicze, szczelinowanie hydrauliczne, płyn szczelinujący, ciecz pozabiegowa 